\title{
The role of educational institutions in globalising language towards sustainable hospitality/tourism development
}

\author{
Cristina G. Gallato* \\ College of Business, \\ Universiti Utara Malaysia \\ 06010 Sintok, Kedah, Malaysia \\ Email: cristina@uum.edu.my \\ *Corresponding author
}

\section{Kristy Aireen Gallato-Reamillo}

Hospitality and Tourism Department,

Saint Paul University Philippines,

Quezon City, Philippines

Email: kristychie@yahoo.com

\section{Ari Warokka and Haim Hilman Abdullah}

College of Business,

Universiti Utara Malaysia,

06010 Sintok, Kedah, Malaysia

Email: ari.warokka@uum.edu.my

Email: hilman@uum.edu.my

\begin{abstract}
In this paper, we address the issue of globalising language in the hospitality/tourism industry, as one of the key ingredients of sustainable development. English is and has been considered as the lingua franca of business, which is acceptable worldwide, and thus, it needs to be promoted as the medium of communication especially in the tourism/hospitality industry. Travellers/tourists often prefer to visit a country where communication is not a problem. Unfortunately, the language barrier is still one of the priority concerns of the hospitality/tourism industry, particularly in some Asian non-English speaking countries. A home/hotel/restaurant/tourist spot/school/office/village/ nation that is friendly communication-wise has always that charm of enticing visitors/guests to come back. Guests that keep on coming back imply repeat business, which ultimately would add figures into the bottom line. Globalising language may help to eliminate the issue of language barriers, and thus help to promote the hospitality/tourism industry.
\end{abstract}

Keywords: global language; English language programme; sustainable development; global competitiveness; tourism industry.

Reference to this paper should be made as follows: Gallato, C.G., GallatoReamillo, K.A., Warokka, A. and Abdullah, H.H. (2012) 'The role of educational institutions in globalising language towards sustainable hospitality/ tourism development', J. Global Business Advancement, Vol. 5, No. 2, pp.115-125. 